\title{
Toxicity Effects of Oral Administration of Clinacanthus nutans Ethanolic Leaf Extract on Blood, Liver and Kidneys of Mice
}

\begin{abstract}
A. ALIYU ${ }^{1 *}$, M. R. SHAARI ${ }^{2}$, NURUL SYAHIRAH AHMAD SAYUTI, M. F. H. REDUAN ${ }^{3}$, SAJJARATTUL NURUL NADIA ASYURA $^{2}$, S. SITHAMBARAM ${ }^{2}$, M. M. NOORDIN, KHOZIRAH SHAARI ${ }^{4,5}$ AND HAZILAWATI HAMZAH

Department of Veterinary Pathology and Microbiology, Faculty of Veterinary Medicine, Universiti Putra Malaysia, Serdang 43400, Selangor, Malaysia, ${ }^{1}$ Department of Veterinary Pathology, Faculty of Veterinary Medicine, Usmanu Danfodiyo University, Sokoto 840212, Sokoto State, Nigeria, ${ }^{2}$ Animal Science Research Centre, Malaysian Agricultural Research and Development Institute Headquarter, Serdang 43400, Selangor, ${ }^{3}$ Department of Paraclinical Studies, Faculty of Veterinary Medicine, Universiti Malaysia Kelantan, Kota Bharu 16100, Kelantan, ${ }^{4}$ Department of Chemistry, Faculty of Science and Environmental Studies, ${ }^{5}$ Laboratory of Natural Products, Institute of Bioscience, Universiti Putra Malaysia, Serdang 43400, Selangor, Malaysia
\end{abstract}

\begin{abstract}
Aliyu et al.: Sub-Chronic Toxicity Effects of Clinacanthus nutans Ethanolic Leaf Extract in Mouse Model
Clinacanthus nutans has been used traditionally in the treatment of herpes simplex viral infection. This research evaluated the toxicity effects of sub-chronic oral administration of Clinacanthus nutans ethanolic leaf extract in Institute of Cancer Research mice. A total 50, $8 \mathrm{w}$ old female mice were divided into five groups of 10 mice each; Group A (control), Group B (125 mg/kg), Group C (250 mg/kg), Group D $(500 \mathrm{mg} / \mathrm{kg})$ and Group $E(1000 \mathrm{mg} / \mathrm{kg})$. The extract was administered orally for $90 \mathrm{~d}$. The mice were monitored and sacrificed on $\mathbf{d} 91$. Blood, liver and kidney samples were collected for analyses. There was significant $(p<0.05)$ alterations in the haematological parameters of the mice in Group $E$ and a significant increase in creatinine levels in groups $B, C, D$ and $E$ compared to $A$. The plasma level of alanine aminotransferase was significantly $(\mathbf{p}<\mathbf{0 . 0 5})$ higher in Groups $D$ and $E$, compared to A. Histopathological evaluation of liver and kidneys revealed a moderate cytoplasmic vacuolation, eosinophilic cytoplasm and pyknosis of hepatocytes, as well as mild to moderate activated Kupffer cells in Group E. Similarly, the renal tubular cells showed mild to moderate renal cytoplasmic vacuolation, eosinophilic cytoplasm, pyknotic and karyolytic cells in Group E. It is concluded that repeated oral doses of Clinacanthus nutans ethanolic leaf extract for $90 \mathrm{~d}$ induced hepato-renal toxicities in female Institute of Cancer Research mice.
\end{abstract}

Key words: Clinacanthus nutans, Institute of Cancer Research mice, sub-chronic toxicity, haematological parameters, liver, kidneys

Clinacanthus nutans (C. nutans), which is locally referred to as "Belalai Gajah" (in Malaysia) belongs to the family Acanthaceae; which is considered as one of the leading families of dicotyledonous flowering plants. The family consists of 250 genera and about 2500 species $^{[1]}$. The genus Clinacanthus consists of two species, C. nutans (Burm. F.) Lindau and C. siamensis Bremek which are found throughout Southeast Asia. The two species have been reported to have different pharmacological activities ${ }^{[2,3]}$. The plant has been used traditionally for the treatment of snake bites, skin rashes, diabetes mellitus, diarrhoea and cancers ${ }^{[4]}$. Moreover, the plant has been used as an anti-viral agent against Herpes Simplex Virus (HSV) and VaricellaZoster Virus $(\mathrm{VZV})^{[3]}$. Interestingly, the leaves of

*Address for correspondence E-mail: abdullahi.aliyu@udusok.edu.ng
C. nutans have gained its popularity as supplement and medicine to treat various types of illnesses including cancer $^{[5]}$. The mode of action of this plant is ascribed to its anti-cell lysis property rather than an antineuromuscular transmission blocker ${ }^{[4]}$. Phytochemical investigation of $C$. nutans extracts revealed the presence of various bioactive compounds including C-glycosyl flavones ${ }^{[6]}$, phytosterols, triterpenoid ${ }^{[7]}$, stigmasterol, glycoglycerolipids ${ }^{[8]}$, lupeol, b-sitosterol, This is an open access article distributed under the terms of the Creative
Commons Attribution-NonCommercial-ShareAlike 3.0 License, which
allows others to remix, tweak, and build upon the work non-commercially,
as long as the author is credited and the new creations are licensed under
the identical terms

Accepted 18 November 2021

Revised 08 April 2021

Received 08 December 2020

Indian J Pharm Sci 2021;83(6):1196-1207 
belutin, sulfur containing glycosides and some compounds related to chlorophyll $\mathrm{A}$ and chlorophyll B. The extraction method has a significant role on the phytochemical yield of $C$. nutans extract ${ }^{[9]}$. Alam et $a l .{ }^{[4]}$ reported that vitexin, isovitexin, schaftoside, isomollupentin 7-O-bglucopyranoside, orientin and isoorientin were isolated from the n-butanol and watersoluble fractions of methanolic extract of this plant in Thailand. Furthermore, a previous study in our group by Aliyu et al. ${ }^{[10]}$ reported that $C$. nutans ethanolic leaf extract cultivated in Pahang, Malaysia contained phytochemical compounds including myricetin, isookanin and ferulic acid ${ }^{[10]}$. These compounds were in addition to those reported earlier by previous researchers $^{[11-13]}$.

Despite these numerous pharmacological potentials of C. nutans, the sub-chronic toxicity effects of ethanolic leaf extract of this plant on the vital organs especially liver and kidney have not been thoroughly investigated. Previous studies have reported the acute and sub-acute $(28 \mathrm{~d})$ toxicity effects of $C$. nutans administration in laboratory rodents ${ }^{[10,14-17]}$. However, treatment of various chronic diseases including cancers required daily administration of the treatment for longer than $28 \mathrm{~d}$ duration. Moreover, Aliyu et al. ${ }^{[10]}$ reported that daily administration of $C$. nutans ethanolic leaf extract for $28 \mathrm{~d}$ induced hepatic and renal toxicity in mice $^{[10]}$. Therefore, it is necessary to evaluate the safety levels of medicinal herbs (including $C$. nutans) when administered for longer duration of $90 \mathrm{~d}$ or more, in order to avoid administering higher doses of the plant that could exert toxic effects on the vital organs in the course of treating chronic illnesses in both humans and animals.

\section{MATERIALS AND METHODS}

\section{Collection of plant materials:}

Leaves of $C$. nutans were collected from the Malaysian Agriculture Research and Development Institute (MARDI) research station, Muadzam Shah, Pahang between the months of July to October 2017. It was processed as described by Aliyu et al. ${ }^{[10]}$. The leaves were cleaned with water and were dried under the sun for $48 \mathrm{~h}$. The leaves were later ground into powdered form and kept at $4^{\circ}$ for subsequent analyses ${ }^{[10,18]}$.

\section{Identification of the plant material:}

The botanical identification of the plant (to confirm its kingdom, family and species) was performed at the Faculty of Science and Technology (FST), University
Kebangsaan Malaysia (UKM). The voucher specimen has been deposited at the herbarium of FST, UKM with reference number: UKMB40367.

\section{Extraction of the plant material:}

The method described by Aliyu et al. ${ }^{[10]}$ was employed. Briefly, about $100 \mathrm{~g}$ of the ground leaf samples was dissolved in about $4000 \mathrm{ml} 95 \%$ ethanol (Merck, German) in a glass flask for the extraction process ${ }^{[10,19]}$. The mixture was placed at $200 \mathrm{rpm}$ at about $25^{\circ}$ (room temperature) in an orbital shaker (Heidoph Unimax 1010, German) for about $2 \mathrm{~h}^{[5,10,20,21]}$. Whatman No. 1 filter paper was used to filter the extract and later concentrated to a semi solid form using a rotary evaporator (BUCHI Rotavapor R-200, Switzerland). The processed extract was stored at $4^{\circ}$ for future analysis.

\section{Preparation of extracts:}

The weekly doses of the extracts were prepared freshly by dissolving the dried extracts of the plants leaf in $5 \%$ Dimethyl Sulfoxide (DMSO) as previously described by Aliyu et al. ${ }^{[10]}$. The doses were prepared based on the average body weight of the mice in each group ${ }^{[10]}$. Five percent $(5 \%)$ DMSO was reported earlier by Nurul et al. ${ }^{[22]}$ not to be associated with any toxicity in rats, therefore, it was chosen as a solvent in this study to dissolve the extract properly prior to the administration.

\section{Animal husbandry and experimental design:}

The animals used in this study were purchased from a commercial vendor at Selangor, Malaysia. The experiment was conducted according to Organisation for Economic Co-operation and Development (OECD) guidelines 408 and was conducted at the Animal Metabolism, Toxicology and Reproductive Centre (AMTREC), Malaysian Agricultural Research and Development Institute (MARDI), Serdang. The experimental animals were treated according to the guide for the care and use of laboratory animals as approved by the Animal Ethics Committee (AEC) of MARDI (20170717/R/MAEC00023). The mice were placed in polycarbonate plastic cages individually and allowed to acclimatize to the housing conditions for $7 \mathrm{~d}$. The housing was conditioned with temperature of $22-25^{\circ}$, humidity at $40 \%-70 \%$ and equal $12 \mathrm{~h}$ light/ dark cycle ${ }^{[10]}$.

A total of 50, $8 \mathrm{w}$ old female mice were randomly allocated into 5 groups of 10 mice each for the study. 
For $90 \mathrm{~d}$, once daily, repeated doses of the extracts were administered orally via oral gavage using stainless steel needle, the details of the doses are shown in Table 1 . The extract was administered at a volume of $1 \mathrm{ml} / 100 \mathrm{~g}$ body weight to Groups B to E accordingly, while Group A received equal volume of distilled water only.

\section{Determination of weekly body weight gain:}

The method of Aliyu et al. ${ }^{[10]}$ was employed for the determination of weekly bodyweight gain of the individual mouse in each of the experimental groups. The weights were measured and recorded accordingly.

\section{Collection of blood and organ samples:}

The mice were humanely sacrificed on $d \quad 91$ of the experiment using Carbon dioxide $\left(\mathrm{CO}_{2}\right)$ chamber ${ }^{[10,23,24]}$. Blood samples were collected through cardiac puncture ${ }^{[10,24]}$ into clean test tubes containing Ethylenediamine Tetraacetic Acid (EDTA) anticoagulant for the analysis of haematology and blood chemistry parameters ${ }^{[10,24-26]}$. Post-mortem was performed on each mouse and tissues from liver, kidney, heart, brain, spleen, lungs and uterus were collected and weighed accordingly ${ }^{[10]}$. The relative organ weight of each organs collected was also determined using the formula below ${ }^{[10,24,27]}$.

Relative organ weight $=$ Organ weight $/$ Body weight $\times 100$

\section{Haematological analyses:}

Automated haematology analyser $\left(\mathrm{ABC} \mathrm{Vet}^{\circledR}, \mathrm{ABX}\right.$ Diagnostics, France) was used for the complete blood count analyses ${ }^{[5,10,24,28]}$.

\section{Clinical biochemistry analysis:}

Plasma sample was obtained by centrifuging the anti-coagulated blood samples collected at $3000 \mathrm{rpm}$ for $15 \mathrm{~min}$ for blood biochemical analyses ${ }^{[24-26,29-32]}$. The plasma was subsequently analysed using fully automated clinical chemistry analyser (BioLis 24i Chemistry Analyzer, Japan) for the concentration of urea, creatinine, Alanine Aminotransferase (ALT),

\begin{tabular}{lc} 
TABLE 1: SUB-CHRONIC & TOXICITY STUDY OF \\
CELE & \\
\hline Group $(\mathbf{n}=10)$ & Treatments \\
\hline A & Control \\
B & $125 \mathrm{mg} / \mathrm{kg} \mathrm{CELE}$ \\
C & $250 \mathrm{mg} / \mathrm{kg} \mathrm{CELE}$ \\
D & $500 \mathrm{mg} / \mathrm{kg}$ CELE \\
E & $1000 \mathrm{mg} / \mathrm{kg} \mathrm{CELE}$ \\
\hline
\end{tabular}

Note: CELE-C. nutans ethanolic leaf extract

November-December 2021

Indian Journal of Pharmaceutical Sciences
Aspartate Aminotransferase (AST), Creatinine Kinase (CK), Total Protein (TP), Albumin (ALB) $)^{[10,24]}$.

\section{Histopathological analyses:}

Liver and kidneys were collected from each mouse as described by Aliyu et al. ${ }^{[10]}$ at the end of the experiment and cleaned using cold normal saline to remove excess blood from the tissues. The method described earlier by Sajjaratul et al. ${ }^{[5]}$, Aliyu et al. ${ }^{[10]}$ and Aliyu et al. ${ }^{[24]}$ were used to process the tissues for Haematoxylin and Eosin (H\&E) stain at the histopathology laboratory, Faculty of Veterinary medicine, Universiti Putra Malaysia. Lesions were evaluated at 4x, 10x, 20x and $40 x$ objective lenses of light microscope ${ }^{[10,24]}$ from each of the processed sample.

\section{Lesion scoring:}

Lesion scoring was conducted according to the method of Aliyu et al. ${ }^{[10]}$. Lesions including eosinophilic cytoplasm, pyknosis, karyolysis, karyorrhexis, activated Kupffer cells, sinusoidal dilatation, cytoplasmic vacuolation, regeneration and inflammation were analysed and scored in each stained section of liver from all groups of mice while hydropic degeneration, pyknosis, inflammation, protein casts, cellular casts and granular casts, were equally scored in the kidneys of each mouse ${ }^{[10]}$. The detailed scores of each lesion and its interpretation are presented in Table 2.

\section{Statistical analysis:}

The results of the study were evaluated using International Business Machines Corporation (IBM) Statistical Package for the Social Sciences (SPSS) statistical software version 23 and were expressed as mean \pm Standard Error of Mean (SEM). One-way Analysis of Variance (ANOVA) with Tukey post hoc test and non-parametric Kruskal-Wallis $\mathrm{H}$ statistical tool were used accordingly to test for significant differences between groups at $\mathrm{p}<0.05^{[10]}$.

\section{RESULTS AND DISCUSSION}

The extract administered daily for $90 \mathrm{~d}$ showed significant $(\mathrm{p}<0.05)$ differences in the average body weight gain of the mice between groups across the $13 \mathrm{w}$ experimental period as determined by repeated measures ANOVA with a Greenhouse-Geisser correction and Bonferroni post hoc (fig. 1). There were $106.51 \%, 112.04 \%, 53.13 \%, 272.73 \%$, $37.56 \%, 28.32 \%, 35.84 \%, 747.73 \%, 149.67 \%$ and $70.09 \%$ reductions in the average body weight gains of 
the mice in Group B at $1^{\text {st }} \mathrm{w}(-0.07 \pm 0.42 \mathrm{~g} ; \mathrm{p}<0.05)$, w $3(-0.14 \pm 0.34 \mathrm{~g} ; \mathrm{p}<0.05)$, w $5(0.42 \pm 0.17 \mathrm{~g} ; \mathrm{p}<0.05)$, w $7(0.40 \pm 0.19 \mathrm{~g} ; \mathrm{p}>0.05)$, w $8(0.40 \pm 0.16 \mathrm{~g} ; \mathrm{p}>0.05)$, w $9(0.41 \pm 0.23 \mathrm{~g} ; \mathrm{p}>0.05), 10(0.29 \pm 0.19 \mathrm{~g} ; \mathrm{p}<0.05)$, $11(-0.08 \pm 0.41 \mathrm{~g} ; \mathrm{p}>0.05)$ and $12(0.14 \pm 0.26 \mathrm{~g} ; \mathrm{p}>0.05)$ of the experiment respectively, compared to Group A at $\mathrm{w} 1(1.12 \pm 0.43 \mathrm{~g})$, w $3(1.20 \pm 0.17 \mathrm{~g})$, w $5(0.89$ $\pm 0.34 \mathrm{~g})$, w $7(0.64 \pm 0.27 \mathrm{~g})$, w $8(0.56 \pm 0.25 \mathrm{~g})$, w $9(0.64$ $\pm 0.28 \mathrm{~g})$, w $10(-0.04 \pm 0.18 \mathrm{~g})$, w $11(0.15 \pm 0.18 \mathrm{~g})$ and $\mathrm{w}$ $12(0.46 \pm 0.27 \mathrm{~g})$ (fig. 1). Furthermore, the mice in Group C showed $61.11 \%, 6.78 \%, 107.61 \%$, $13.18 \%, 79.31 \%, 241.67 \%, 95.93 \%, 81.72 \%, 129.55 \%$, $103.06 \%$ and $25.95 \%$ reductions in the average body weight gains at w $1(0.44 \pm 0.36 \mathrm{~g} ; \mathrm{p}<0.05)$, w 2 $(0.65 \pm 0.20 \mathrm{~g} ; \mathrm{p}>0.05)$, w $3(-0.09 \pm 0.20 \mathrm{~g} ; \mathrm{p}<0.05)$, w $4(0.61 \pm 0.25 \mathrm{~g} ; \mathrm{p}>0.05)$, w $5(0.19 \pm 0.25 \mathrm{~g} ; \mathrm{p}<0.05)$, w $7(0.03 \pm 0.17 \mathrm{~g} ; \mathrm{p}>0.05)$, w $8(0.10 \pm 0.13 \mathrm{~g} ; \mathrm{p}<0.05)$, w $10(0.01 \pm 0.26 \mathrm{~g} ; \mathrm{p}>0.05)$, w $12(-0.01 \pm 0.18 \mathrm{~g}$; $\mathrm{p}<0.05)$ and $\mathrm{w} 13(0.21 \pm 0.18 \mathrm{~g} ; \mathrm{p}>0.05)$ of the experiment respectively, compared to Group A gains at w $1(1.12 \pm 0.43 \mathrm{~g})$, w $2(0.69 \pm 0.16 \mathrm{~g})$, w 3

TABLE 2: INTERPRETATION OF SCORES IN LIVER AND KIDNEY LESION SCORING FOR THE TOXICITY STUDIES OF CELE IN ICR MICE

\begin{tabular}{lcc}
\hline *Score & Percentage & Severity \\
\hline 0 & None & None \\
1 & Less than $10 \%$ & Mild \\
1.5 & $10-30 \%$ & Mild-moderate \\
2 & $30-50 \%$ & Moderate \\
2.5 & $50-70 \%$ & Moderate-severe \\
3 & More than $70 \%$ & Severe \\
\hline
\end{tabular}

Note: CELE-C. nutans ethanolic leaf extract; *-adopted from Aliyu et al. ${ }^{[10]}$
$(1.20 \pm 0.17 \mathrm{~g})$, w $4(0.70 \pm 0.36 \mathrm{~g})$, w $5(0.89 \pm 0.34 \mathrm{~g})$, w $7(0.64 \pm 0.27 \mathrm{~g})$, w $8(0.56 \pm 0.25 \mathrm{~g})$, w $10(-0.04$ $\pm 0.18 \mathrm{~g})$, w $12(0.46 \pm 0.27 \mathrm{~g})$ and $\mathrm{w} 13(0.29 \pm 0.52 \mathrm{~g})$ (fig. 1). Similarly, there were $140.05 \%, 87.12 \%, 89.59$ $\%, 456.06 \%, 69.48 \%, 97.13 \%$ and $71.28 \%$ significant $(p<0.05)$ decrease in the average body weight gains of the mice in Group D at w $1(-0.45 \pm 0.40 \mathrm{~g} ; \mathrm{p}<0.05)$, w 3 (0.15 $\pm 0.28 \mathrm{~g} ; \mathrm{p}<0.05)$, w $5(0.09 \pm 0.17 \mathrm{~g} ; \mathrm{p}<0.05)$, w $7(0.20 \pm 0.19 \mathrm{~g} ; \mathrm{p}<0.05)$, w $8(0.02 \pm 0.26 \mathrm{~g} ; \mathrm{p}<0.05)$ and $\mathrm{w} 13(0.08 \pm 0.19 \mathrm{~g} ; \mathrm{p}>0.05)$ of the experiment respectively, compared to those in Group A at w 1 $(1.12 \pm 0.43 \mathrm{~g})$, w $3(1.20 \pm 0.17 \mathrm{~g})$, w $5(0.89 \pm 0.34 \mathrm{~g})$, w $7(0.64 \pm 0.27 \mathrm{~g})$, w $8(0.56 \pm 0.25 \mathrm{~g})$ and w $13(0.29$ $\pm 0.52 \mathrm{~g}$ ) (fig. 1). In addition, the treated mice in Group D also showed $78.07 \%, 9.17 \%, 17.99 \%, 327.27 \%$, $71.24 \%$ and $13.32 \%$ increases in the average body weight gains at $w 2(1.23 \pm 0.41 \mathrm{~g} ; \mathrm{p}>0.05), \mathrm{w} 4(0.76 \pm 0.32$ $\mathrm{g} ; \mathrm{p}>0.05)$, w $9(0.75 \pm 0.18 \mathrm{~g} ; \mathrm{p}>0.05), w 10(-0.19 \pm 0.12$ $\mathrm{g} ; \mathrm{p}>0.05)$, w $11(0.26 \pm 0.31 \mathrm{~g} ; \mathrm{p}>0.05)$ and $\mathrm{w} 12$ $(0.52 \pm 0.22 \mathrm{~g} ; \mathrm{p}>0.05)$ of the experiment respectively, compared to the mice in Group A at w $2(0.69 \pm 0.16 \mathrm{~g})$, w $4(0.70 \pm 0.36 \mathrm{~g})$, w $9(0.64 \pm 0.28 \mathrm{~g})$, w $10(-0.04 \pm 0.18$ g), w $11(0.15 \pm 0.18 \mathrm{~g})$ and w $12(0.46 \pm 0.27 \mathrm{~g})$ (fig. 1). Moreover, there were $106.16 \%, 83.36 \%, 48.21 \%$, $85.92 \%, 131.00 \%, 44.91 \%, 1415.91 \%, 496.73 \%$, $59.39 \%$ and $96.65 \%$ reductions in the average body weight gains of the mice in Group E, at w $1(-0.07 \pm 0.40$ $\mathrm{g} ; \mathrm{p}<0.05)$, w $3(0.20 \pm 0.23 \mathrm{~g} ; \mathrm{p}<0.05)$, w $5(0.46 \pm 0.20$ g; $<<0.05)$, w $7(0.09 \pm 0.31 \mathrm{~g} ; \mathrm{p}<0.05)$, w $8(-0.17 \pm 0.58$ $\mathrm{g} ; \mathrm{p}<0.05)$, w $9(0.35 \pm 0.12 \mathrm{~g} ; \mathrm{p}>0.05)$, w $11(-0.61 \pm 0.28$ $\mathrm{g} ; \mathrm{p}<0.05)$, w $12(0.19 \pm 0.73 \mathrm{~g} ; \mathrm{p}<0.05)$ and $\mathrm{w} 13$ $(0.00 \pm 0.35 \mathrm{~g} ; \mathrm{p}>0.05)$ of the experiment respectively,

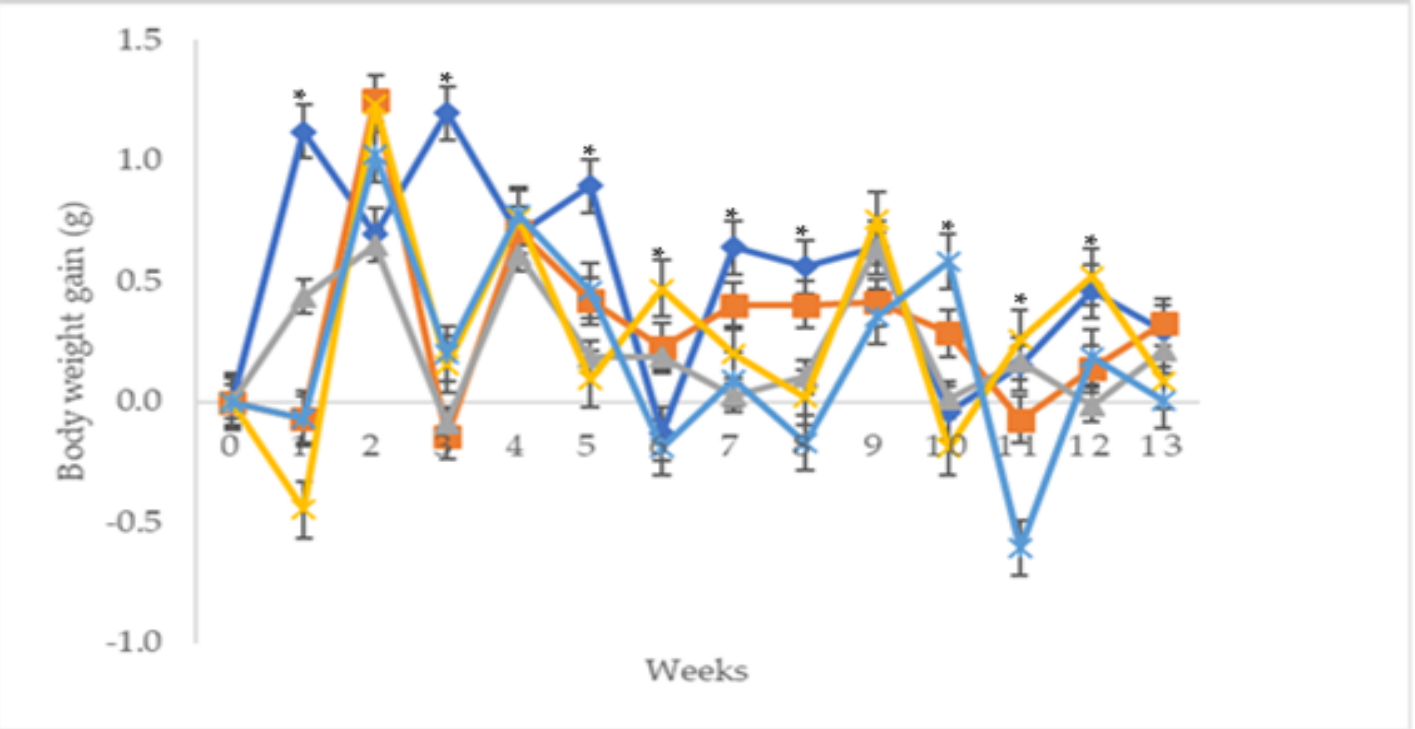

Fig. 1: Average (mean \pm SEM) weekly body weight gain (g) of female ICR mice in sub-chronic toxicity study of CELE. A-control; F-125 mg/kg CELE; G-250 mg/kg CELE; H-500 mg/kg CELE; I-1000 mg/kg CELE; *differ significantly at p<0.05; SEM-standard

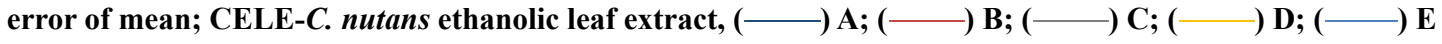


compared to Group A at w $1(1.12 \pm 0.43 \mathrm{~g})$, w 3 (1.20 $\pm 0.17 \mathrm{~g})$, w $5(0.89 \pm 0.34 \mathrm{~g})$, w $7(0.64 \pm 0.27 \mathrm{~g})$, w $8(0.56$ $\pm 0.25 \mathrm{~g})$, w $9(0.64 \pm 0.28 \mathrm{~g}), \mathrm{w} 11(0.15 \pm 0.18 \mathrm{~g}), \mathrm{w} 12(0.46$ $\pm 0.27 \mathrm{~g})$ and $\mathrm{w} 13(0.29 \pm 0.52 \mathrm{~g})$ (fig. 1).

Table 3 showed that there were no statistically significant $(p>0.05)$ differences between groups in the relative organs weight of the mice treated with C. nutans Ethanolic Leaf Extract (CELE) daily for $90 \mathrm{~d}$, as determined by one-way ANOVA (Table 3). However, there was $26.5 \%(\mathrm{p}>0.05)$ decrease in the relative weight of brain in Group E $(1.67 \pm 0.05 \%)$ compared to A $(2.27 \pm 0.10 \%)$. Similarly, the relative weights of uterus were $33.1 \%, 31.5 \%, 30.6 \%$ and $37.1 \%$ lower respectively in Groups B $(0.83 \pm 0.03 \%), \mathrm{C}(0.85$ $\pm 0.05 \%), \mathrm{D}(0.86 \pm 0.06 \%)$ and $\mathrm{E}(0.78 \pm 0.03 \%)$ compared to $\mathrm{A}(1.24 \pm 0.17 \%)$ (Table 3$)$. Furthermore, the relative organs weights of right kidney were $14.6 \%$ and $16.9 \%$ lower $(\mathrm{p}>0.05)$ in Groups $\mathrm{C}(0.76 \pm 0.02)$ and
$\mathrm{E}(0.74 \pm 0.03)$ respectively, compared to $\mathrm{A}(0.89 \pm 0.08)$ (Table 3).

There were statistically significant $(p<0.05)$ differences between groups in the haematological parameters of the mice treated with different doses of CELE daily for $90 \mathrm{~d}$ as determined by one-way ANOVA(Table 4). Tukey post hoc test demonstrated sub-chronic administration of CELE showed $21.2 \%, 9.1 \%$ and $9.1 \%$ significant $(p<0.05)$ increases in the values of Packed Cell Volume (PCV) respectively in Groups C $(0.40 \pm 0.021 / 1)$, D $(0.36 \pm 0.021 / 1)$ and $E(0.36 \pm 0.031 / 1)$ of the mice, compared to A $(0.33 \pm .021 / 1)$ (Table 4). Furthermore, there was $61.7 \%$ significant $(\mathrm{p}<0.05)$ increase in total leucocyte counts in Group E $\left(11.85 \pm 0.69 \times 10^{9} / 1\right)$ compared to A $\left(7.33 \pm 0.45 \times 10^{9} / 1\right)$. The increase in total leucocyte count was accompanied by significant $(\mathrm{p}<0.05)$ increase in neutrophils $(67.3 \%)$ in Group E $\left(3.38 \pm 0.289 \times 10^{9} / 1\right)$ compared to A $\left(2.02 \pm 0.16 \times 10^{9} / 1\right)$,

TABLE 3: RELATIVE ORGAN WEIGHTS IN PERCENTAGE (\%) (MEAN士SEM) OF FEMALE ICR MICE IN SUBCHRONIC TOXICITY STUDY OF CELE

\begin{tabular}{lccccc}
\hline Organs & $\mathrm{A}$ & $\mathrm{B}$ & $\mathrm{C}$ & $\mathrm{D}$ & $\mathrm{E}$ \\
\hline Liver & $6.49 \pm 0.36$ & $7.40 \pm 0.39$ & $6.52 \pm 0.26$ & $6.30 \pm 0.24$ & $6.25 \pm 0.22$ \\
Right Kidney & $0.89 \pm 0.08$ & $0.84 \pm 0.04$ & $0.76 \pm 0.02$ & $0.83 \pm 0.05$ & $0.74 \pm 0.03$ \\
Left kidney & $0.82 \pm 0.05$ & $0.85 \pm 0.03$ & $0.76 \pm 0.03$ & $0.80 \pm 0.03$ & $0.74 \pm 0.03$ \\
Spleen & $0.62 \pm 0.06$ & $0.63 \pm 0.05$ & $0.58 \pm 0.08$ & $0.76 \pm 0.06$ & $0.62 \pm 0.10$ \\
Heart & $0.67 \pm 0.05$ & $0.76 \pm 0.05$ & $0.69 \pm 0.04$ & $0.67 \pm 0.05$ & $0.65 \pm 0.04$ \\
Lungs & $1.43 \pm 0.07$ & $1.43 \pm 0.13$ & $1.46 \pm 0.10$ & $1.29 \pm 0.12$ & $1.58 \pm 0.23$ \\
Brain & $2.27 \pm 0.10$ & $2.21 \pm 0.09$ & $2.08 \pm 0.08$ & $1.97 \pm 0.06$ & $1.67 \pm 0.05$ \\
Uterus & $1.24 \pm 0.17$ & $0.83 \pm 0.03$ & $0.85 \pm 0.05$ & $0.86 \pm 0.06$ & $0.78 \pm 0.03$ \\
\hline
\end{tabular}

Note: CELE-C. nutans ethanolic leaf extract; A-Control; B-125 mg/kg CELE; C-250 mg/kg CELE; D-500 mg/kg CELE; E-1000 mg/kg CELE; Values in the same row without asterisk are comparable $(p>0.05)$

TABLE 4: HAEMATOLOGICAL PARAMETERS (MEAN \pm SEM) OF FEMALE ICR MICE IN SUB-CHRONIC TOXICITY STUDY OF CELE

\begin{tabular}{lccccc}
\hline Parameters & A & B & C & D & E \\
\hline Red blood cells $\left(\times 10^{12} / \mathrm{l}\right)$ & $9.50 \pm 0.25$ & $9.90 \pm 0.31$ & $9.79 \pm 0.29$ & $9.11 \pm 0.23$ & $9.56 \pm 0.30$ \\
Haemoglobin $(\mathrm{g} / \mathrm{l})$ & $158.40 \pm 3.3$ & $170.10 \pm 3.9$ & $163.40 \pm 4.3$ & $153.10 \pm 5.1$ & $159.89 \pm 6.0$ \\
PCV $(\mathrm{l} / \mathrm{l})$ & $0.33 \pm 0.02$ & $0.40 \pm 0.02^{*}$ & $0.37 \pm 0.01$ & $0.36 \pm 0.02^{*}$ & $0.36 \pm 0.03^{*}$ \\
Platelets $\left(\times 10^{9} / \mathrm{l}\right)$ & $871.6 \pm 124$ & $1126.0 \pm 154$ & $821.2 \pm 130$ & $840.1 \pm 137^{\mathrm{a}}$ & $1175.1 \pm 132$ \\
MCV $(\mathrm{fl})$ & $65.80 \pm 0.79$ & $67.20 \pm 0.76$ & $66.20 \pm 1.05$ & $64.60 \pm 0.98^{\mathrm{a}}$ & $65.33 \pm 1.09$ \\
MCH $(\mathrm{pg})$ & $16.71 \pm 0.33$ & $17.33 \pm 0.25$ & $16.75 \pm 0.30$ & $16.80 \pm 0.39^{\mathrm{a}}$ & $16.70 \pm 0.32$ \\
MCHC $(\mathrm{g} / \mathrm{l})$ & $253.50 \pm 3.5$ & $257.60 \pm 3.5$ & $253.10 \pm 2.3$ & $259.00 \pm 3.9^{\mathrm{a}}$ & $255.67 \pm 3.7$ \\
Plasma proteins $(\mathrm{g} / \mathrm{l})$ & $77.60 \pm 3.34$ & $82.00 \pm 2.02$ & $80.50 \pm 1.71$ & $80.60 \pm 1.55^{\mathrm{a}}$ & $84.89 \pm 3.74$ \\
WBCs $\left(\times 10^{9} / \mathrm{l}\right)$ & $7.33 \pm 0.45$ & $10.07 \pm 0.589^{*}$ & $6.81 \pm 0.44$ & $8.72 \pm 0.67$ & $11.85 \pm 0.69^{*}$ \\
Neutrophils $\left(\times 10^{9} / \mathrm{l}\right)$ & $2.02 \pm 0.16$ & $2.73 \pm .20$ & $1.81 \pm 0.17$ & $2.52 \pm 0.20$ & $3.38 \pm 0.289^{*}$ \\
Lymphocytes $\left(\times 10^{9} / \mathrm{l}\right)$ & $4.59 \pm 0.31$ & $6.68 \pm 0.449^{*}$ & $4.57 \pm 0.34$ & $5.62 \pm 0.49$ & $7.55 \pm 0.379^{*}$ \\
Monocytes $\left(\times 10^{9} / \mathrm{l}\right)$ & $0.47 \pm 0.03$ & $0.46 \pm 0.03$ & $0.34 \pm 0.02$ & $0.43 \pm 0.04$ & $0.63 \pm 0.049^{*}$ \\
Eosinophils $\left(\times 10^{9} / \mathrm{l}\right)$ & $0.24 \pm 0.04$ & $0.20 \pm 0.02$ & $0.09 \pm 0.01$ & $0.16 \pm 0.02$ & $0.29 \pm 0.049^{*}$ \\
Basophils $\left(\times 10^{9} / \mathrm{l}\right)$ & $0.00 \pm 0.00$ & $0.00 \pm 0.00$ & $0.00 \pm 0.00$ & $0.00 \pm 0.00$ & $0.00 \pm 0.00$ \\
\hline
\end{tabular}

Note: CELE-C. nutans ethanolic leaf extract; A-Control; B-125 mg/kg CELE, C-250 mg/kg CELE; D-500 mg/kg CELE; E-1000 mg/kg CELE; PCV-Packed cell volume; MCV-Mean corpuscular volume; MCH-Mean corpuscular haemoglobin; MCHC-Mean corpuscular haemoglobin concentration; Values in the same row with asterisk are not comparable $(p<0.05)$ 
significant $(\mathrm{p}<0.05)$ increase in lymphocyte counts $(64.5 \%)$ in Group E $\left(7.55 \pm 0.379 \times 10^{9} / 1\right)$ compared to A $\left(4.59 \pm 0.31 \times 10^{9} / 1\right)$, significant $(\mathrm{p}<0.05)$ increase in monocyte count $(34 \%)$ in Group E $\left(0.63 \pm 0.049 \times 10^{9} / 1\right)$ compared to A $\left(0.47 \pm 0.03 \times 10^{9} / 1\right)$, as well as $20 \%$ significant $(\mathrm{p}<0.05)$ increase in eosinophil counts in Group E $\left(0.29 \pm 0.049 \times 10^{9} / 1\right)$ compared to A $(0.24 \pm 0.04)$ (Table 4).

The levels of the plasma biochemical parameters of the mice treated with varying doses of CELE subchronically (90 d) are shown on Table 5 . There were statistically significant $(\mathrm{p}<0.05)$ differences between groups in the plasma biochemical parameters of the mice as demonstrated by one-way ANOVA (Table 5). Tukey post hoc test revealed that the mice treated with CELE had $45.4 \%$ significant $(\mathrm{p}<0.05)$ increase in the urea in Group E $(10.22 \pm 0.74 \mathrm{mmol} / \mathrm{l})$ compared to A $(7.03 \pm 0.25 \mathrm{mmol} / \mathrm{l})$ as well as $37 \%, 45.6 \%, 40.3 \%$ and $41.6 \%$ significant $(\mathrm{p}<0.05)$ increases in creatinine levels respectively in Groups B $(41.80 \pm 1.17 \mu \mathrm{mol} / \mathrm{l})$, C $(44.40 \pm 0.99 \mu \mathrm{mol} / \mathrm{l}), \mathrm{D}(42.80 \pm 1.71 \mu \mathrm{mol} / \mathrm{l})$ and $\mathrm{E}$ $(43.24 \pm 2.25 \mu \mathrm{mol} / 1)$ compared to $\mathrm{A}(30.50 \pm 1.31 \mu \mathrm{mol} / \mathrm{l})$ (Table 5). Additionally, the plasma levels of ALT were $78 \%$ and $51.6 \%$ significantly $(\mathrm{p}<0.05)$ higher respectively in Groups D $(425.60 \pm 25.64 \mathrm{U} / 1)$ and $\mathrm{E}$ (362.52 $\pm 27.01 \mathrm{U} / 1)$ compared to A $(239.10 \pm 22.50 \mathrm{U} / 1)$.
There were also $67.7 \%$ and $70.2 \%$ significant $(\mathrm{p}<0.05)$ increase in AST in Groups D (348.60 $\pm 21.45 \mathrm{U} / 1)$ and E $(353.85 \pm 16.84 \mathrm{U} / 1)$ respectively, compared to A $(207.90 \pm 19.67 \mathrm{U} / \mathrm{l})$ as well as $138 \%$ significant $(\mathrm{p}<0.05)$ increase in CK level in Group D $(1516.1 \pm 150.15 \mathrm{U} / \mathrm{l})$ compared to A (636.8 $\pm 45.81 \mathrm{U} / 1)$ (Table 5).

Histological evaluation of the samples from the varying groups of mice with administration of different doses of CELE and distilled water daily for $90 \mathrm{~d}$ showed significant $(p<0.05)$ differences in the lesion score between the different treatment groups as determined by Kruskal-Wallis H test (Table 6). Pairwise comparisons test showed a moderate eosinophilic cytoplasm (fig. 2B and fig. 2D) in Group E (2.15 \pm 0.20$)$ compared to $\mathrm{A}(0.00 \pm 0.00)$, moderate cytoplasmic vacuolation (fig. 2D) in Group E (2.20 \pm 0.15$)$ and moderate pyknosis (fig. 2B and fig. 2D) of the hepatocytes in Group E (2.05 \pm 0.26$)$ compared to A $(0.00 \pm 0.00)$ (Table 6). There was also mild to moderate karyolysis of the hepatocytes in Group E (1.85 \pm 0.22$)$ compared to A $(0.00 \pm 0.00)$. There was significant mild to moderate activated Kupffer cells in Group E (1.85 \pm 0.22$)$ compared to $\mathrm{A}(0.00 \pm 0.00)$, hepatic regeneration in Group E (1.90 \pm 0.07$)$ compared to A $(0.55 \pm 0.24)$. Moreover, Group E showed significant $\mathrm{p}<0.05$ mild cellular infiltrations (fig. $2 \mathrm{C}$ and fig. 2D) $(1.60 \pm 0.21)$

TABLE 5: BIOCHEMICAL PARAMETERS (MEAN STUDY OF CELE

\begin{tabular}{lccccc}
\hline Parameters & A & B & C & D & E \\
\hline Urea $(\mathrm{mmol} / \mathrm{l})$ & $7.03 \pm 0.25$ & $9.54 \pm 0.62$ & $9.36 \pm 0.88$ & $8.02 \pm 0.41$ & $10.22 \pm 0.74^{*}$ \\
Creatinine $(\mu \mathrm{mol} / \mathrm{l})$ & $30.50 \pm 1.31^{*}$ & $41.80 \pm 1.17$ & $44.40 \pm 0.99$ & $42.80 \pm 1.71$ & $43.24 \pm 2.25$ \\
ALT $(\mathrm{U} / \mathrm{l})$ & $239.10 \pm 22.5$ & $326.30 \pm 15.1$ & $336.20 \pm 27.7^{*}$ & $425.60 \pm 25.6^{*}$ & $362.52 \pm 27.0^{*}$ \\
AST $(\mathrm{U} / \mathrm{l})$ & $207.90 \pm 19.7^{*}$ & $304.30 \pm 19.0$ & $304.60 \pm 15.3$ & $348.60 \pm 21.5$ & $353.85 \pm 16.8$ \\
CK $(\mathrm{U} / \mathrm{l})$ & $636.8 \pm 45.81$ & $574.0 \pm 52.27$ & $648.9 \pm 70.86$ & $1516.1 \pm 150.15^{*}$ & $716.5 \pm 74.90$ \\
TP $(\mathrm{g} / \mathrm{l})$ & $57.58 \pm 4.20$ & $58.24 \pm 1.65$ & $55.22 \pm 1.52$ & $58.46 \pm 2.19$ & $59.73 \pm 2.35$ \\
ALB $(\mathrm{g} / \mathrm{l})$ & $32.05 \pm 2.01$ & $31.34 \pm 0.76$ & $32.08 \pm 1.44$ & $31.19 \pm 0.89$ & $34.27 \pm 1.79$ \\
Globulins $(\mathrm{g} / \mathrm{l})$ & $25.53 \pm 2.66$ & $26.90 \pm 1.30$ & $23.14 \pm 1.00$ & $27.27 \pm 1.88$ & $25.47 \pm 2.55$ \\
\hline
\end{tabular}

Note: CELE-C. nutans ethanolic leaf extract; A-Control; B-125 mg/kg CELE; C-250 mg/kg CELE; D-500 mg/kg CELE; E-1000 mg/kg CELE; values in the same row with asterisk differ significantly $(p<0.05)$

TABLE 6: LESION SCORES (MEAN \pm SEM) OF THE LIVER OF FEMALE ICR MICE IN SUB-CHRONIC TOXICITY STUDY OF CELE

\begin{tabular}{lccccc}
\hline Lesions & $\mathrm{A}$ & $\mathrm{B}$ & $\mathrm{C}$ & $\mathrm{D}$ & $\mathrm{E}$ \\
\hline Hydropic degeneration & $0.35 \pm 0.18$ & $0.00 \pm 0.00$ & $0.00 \pm 0.00$ & $0.30 \pm 0.20$ & $2.20 \pm 0.15^{*}$ \\
Eosinophilic cytoplasm & $0.00 \pm 0.00$ & $0.10 \pm 0.10$ & $0.30 \pm 0.15$ & $0.40 \pm 0.28$ & $2.15 \pm 0.20^{*}$ \\
Pyknosis & $0.00 \pm 0.00$ & $0.00 \pm 0.00$ & $0.00 \pm 0.00$ & $0.35 \pm 0.24$ & $2.05 \pm 0.26^{*}$ \\
Karyolysis & $0.00 \pm 0.00$ & $0.00 \pm 0.00$ & $0.00 \pm 0.00$ & $0.00 \pm 0.00$ & $1.85 \pm 0.22^{*}$ \\
Sinusoidal dilatation & $0.00 \pm 0.00$ & $0.00 \pm 0.00$ & $0.00 \pm 0.00$ & $0.15 \pm 0.15$ & $0.85 \pm 0.32^{*}$ \\
Activated Kupffer cells & $0.00 \pm 0.00$ & $0.15 \pm 0.15$ & $0.00 \pm 0.00$ & $0.00 \pm 0.00$ & $1.85 \pm 0.22^{*}$ \\
Inflammation & $0.10 \pm 0.10$ & $0.45 \pm 0.19$ & $0.30 \pm 0.15$ & $0.60 \pm 0.21$ & $1.60 \pm 0.21^{*}$ \\
Regeneration & $0.55 \pm 0.24$ & $1.75 \pm 0.21^{*}$ & $0.95 \pm 0.17$ & $1.30 \pm 0.19$ & $1.90 \pm 0.07^{*}$ \\
\hline
\end{tabular}

Note: CELE-C. nutans ethanolic leaf extract; A-Control; B-125 mg/kg CELE; C-250 mg/kg CELE; D-500 mg/kg CELE; E-1000 mg/kg CELE; *-significantly different at $\mathrm{p}<0.05$ 

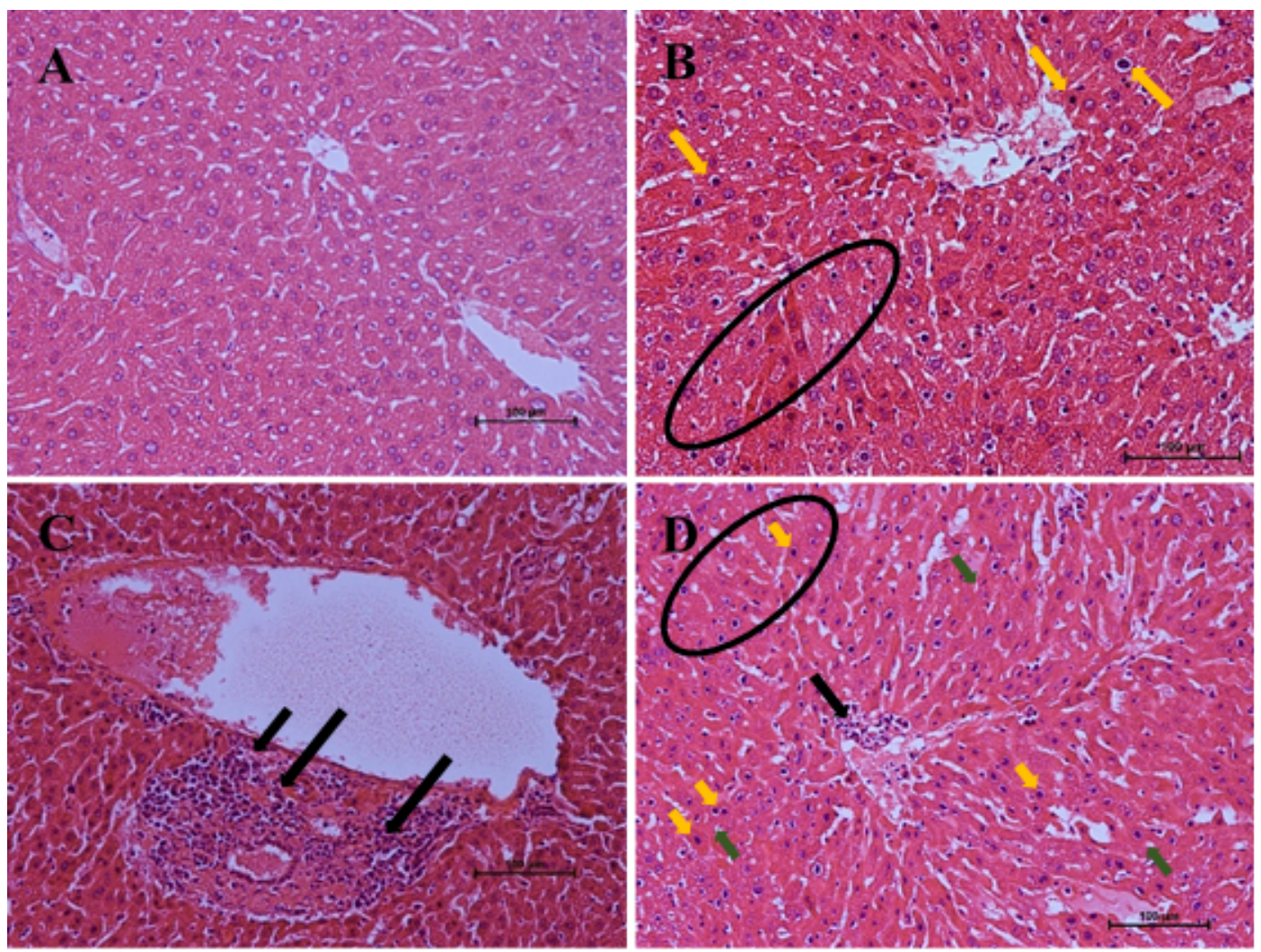

Fig. 2: Effects of repeated oral administration of CELE for $90 \mathrm{~d}$ on the histology of liver of female ICR mice. (A) Photomicrograph of a liver section (H\&E stain 200x) from a mouse in Group A (control) showing normal architecture of liver; (B) In Group D $(500 \mathrm{mg} / \mathrm{kg}$ CELE) showing eosinophilic cytoplasm (encircled) and pyknosis of the hepatocytes (yellow arrow); (C) In Group D (500 mg/kg CELE) showing cellular infiltration (black arrows); (D) In Group E (1000 mg/kg CELE) showing vacuolation (green arrows), eosinophilic cytoplasm (encircled) and pyknosis of the hepatocytes (yellow arrows) as well as cellular infiltrations (black arrows); H\&E-Haematoxylin and Eosin; CELE-C. nutans ethanolic leaf extract; Scale bars represent $100 \mu$

compared to Group A $(0.10 \pm 0.10)$. These findings correspond to those of plasma biochemistry, where there were statistically significant $(\mathrm{p}<0.05)$ differences in the liver parameters between the control and treatment groups (Table 5).

The histopathologic effects of oral administration of different doses of CELE daily for $90 \mathrm{~d}$ on the kidneys of female Institute of Cancer Research (ICR) mice are presented on Table 7. Kruskal-Wallis $\mathrm{H}$ test showed statistically significant $(\mathrm{p}<0.05)$ differences in the lesion score between the different treatment groups (Table 7). Pairwise comparisons test revealed a mild to moderate renal cytoplasmic vacuolation (fig. 3B and fig. 3D) in Group E ( $1.80 \pm 0.08)$ compared to $\mathrm{A}(0.00 \pm 0.00)$. There was moderate renal necrosis characterised by significant $(\mathrm{p}<0.05)$ eosinophilic cytoplasm $(1.75 \pm 0.24)$ in Group E (fig. 3C) compared to A $(0.00 \pm 0.00)$. Furthermore, there was mild $(p<0.05)$ pyknosis $(0.90 \pm 0.27)$ and karyolysis $(0.60 \pm 0.26)$ of the renal tubules in Group E compared to A $(0.00 \pm 0.00)$. Furthermore, there was mild $(\mathrm{p}<0.05)$ inflammatory cellular infiltration (fig. 3B and fig. 3D) in Groups D $(0.90 \pm 0.21)$ and $\mathrm{E}(0.75 \pm 0.25)$ compared to $\mathrm{A}(0.00 \pm 0.00)$ (Table 7).
Evaluation of toxic effects of plants is very essential in determining its safety in both human and animal subjects. Toxicological studies are usually performed in animals to establish the effects of a chemical or substance on their biological system, to predict the possible effects and/or doses of the same substance in humans ${ }^{[33,34]}$. Liver and kidney are the main organs for consideration in oral toxicity study. This is because compounds administrated orally are metabolized by the liver and excreted by the kidney ${ }^{[35]}$. Acute toxicity study may possibly provide significant information that could help in identifying the targeted organs of the test substances following acute exposure ${ }^{[35]}$. However, sub-acute and sub-chronic toxicity studies assess the adverse effects of repeated administration of a chemical or substance on certain parameters of experimental animals. This is to generate evidences on the target-organ toxicity and bioaccumulation potentials of the substance, which are essential in determining the No-Observed-AdverseEffect Levels (NOAELs), in order to establish doses for human exposure ${ }^{[15]}$. The relative internal organ weights provide information as whether or otherwise the organs are affected by the administration of the test substance. 
TABLE 7: LESION SCORES (MEAN土SEM) OF THE KIDNEY OF FEMALE ICR MICE IN SUB-CHRONIC TOXICITY STUDY OF CELE

\begin{tabular}{lccccc}
\hline Lesions & A & B & C & D & E \\
\hline Hydropic degeneration & $0.00 \pm 0.00$ & $0.35 \pm 0.24$ & $0.00 \pm 0.00$ & $0.80 \pm 0.27$ & $1.80 \pm 0.08^{*}$ \\
Eosinophilic cytoplasm & $0.10 \pm 0.10$ & $0.40 \pm 0.28$ & $0.00 \pm 0.00$ & $1.20 \pm 0.27$ & $1.75 \pm 0.24^{*}$ \\
Pyknosis & $0.00 \pm 0.00$ & $0.00 \pm 0.00$ & $0.00 \pm 0.00$ & $0.00 \pm 0.00$ & $0.90 \pm 0.27^{*}$ \\
Karyolysis & $0.00 \pm 0.00$ & $0.00 \pm 0.00$ & $0.00 \pm 0.00$ & $0.00 \pm 0.00$ & $0.60 \pm 0.26^{*}$ \\
Nephritis & $0.30 \pm 0.15$ & $0.20 \pm 0.13$ & $0.15 \pm 0.15$ & $0.90 \pm 0.21^{*}$ & $0.75 \pm 0.25^{*}$ \\
Protein casts & $0.65 \pm 0.18$ & $0.10 \pm 0.10$ & $0.20 \pm 0.13$ & $0.30 \pm 0.15$ & $0.40 \pm 0.16$ \\
Cellular casts & $0.00 \pm 0.00$ & $0.00 \pm 0.00$ & $0.00 \pm 0.00$ & $0.00 \pm 0.00$ & $0.10 \pm 0.10$ \\
Granular casts & $0.00 \pm 0.00$ & $0.10 \pm 0.10$ & $0.00 \pm 0.00$ & $0.10 \pm 0.10$ & $0.20 \pm 0.13$ \\
\hline
\end{tabular}

Note: CELE-C. nutans ethanolic leaf extract; A-Control; B-125 mg/kg CELE; C-250 mg/kg CELE; D-500 mg/kg CELE; E-1000 mg/kg CELE; *-significantly different at $\mathrm{p}<0.05$
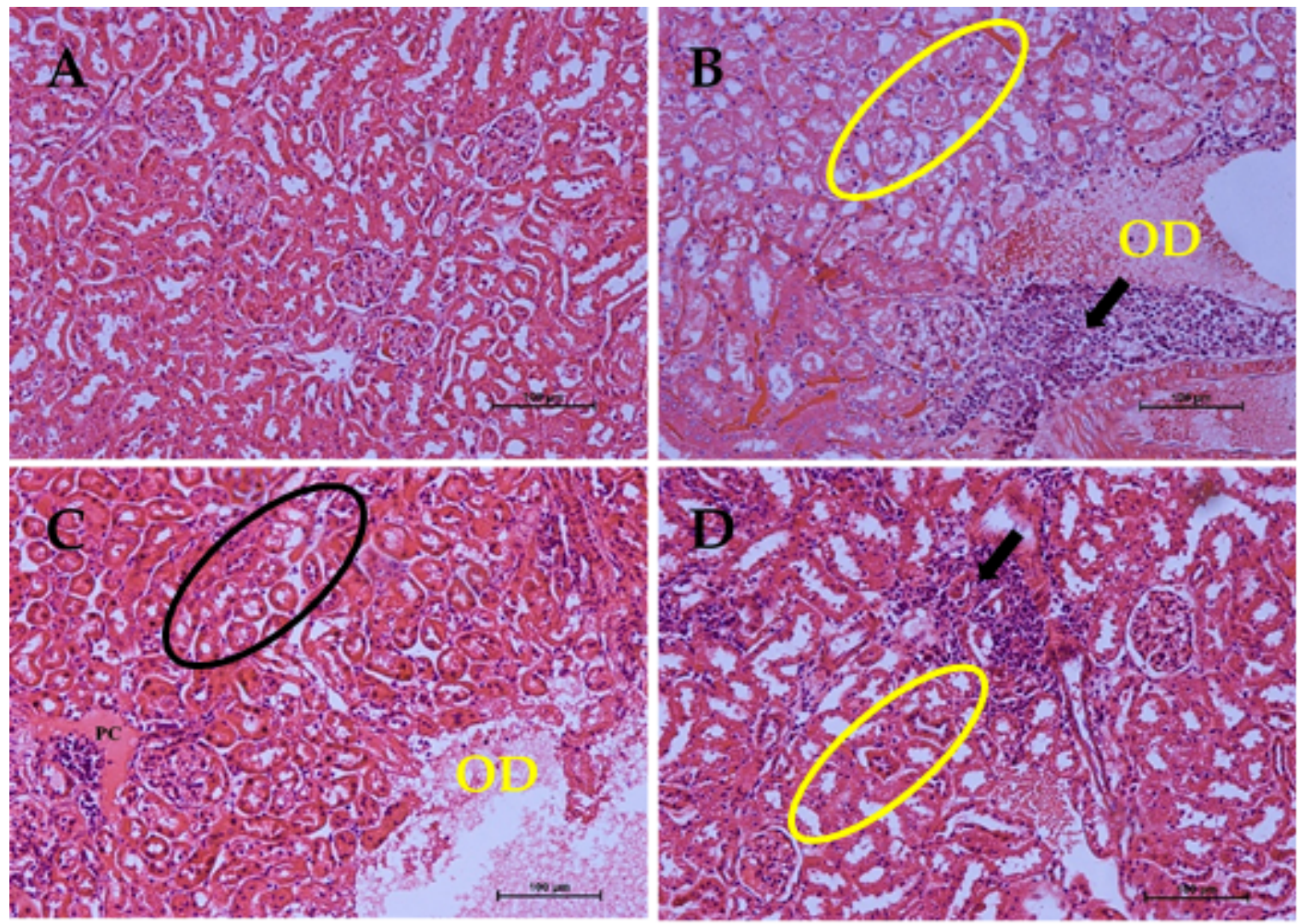

Fig. 3: Effects of repeated oral administration of CELE for $90 \mathrm{~d}$ on the histology of kidney of female ICR mice. (A) Photomicrograph of a kidney section (H\&E stain, 200x) from a mouse in Group A (control) showing normal structure of kidney; (B) In Group C ( $250 \mathrm{mg} / \mathrm{kg}$ CELE) showing vacuolation of the renal tubules (yellow encircled), cellular infiltration (black arrow) and oedema (OD); (C) In Group E (1000 mg/kg CELE) showing eosinophilic cytoplasm (black encircled) and oedema (OD); (D) In Group E, showing cellular infiltration (Black arrow) and vacuolation of the renal tubular cells (yellow encircled); H\&E-Haematoxylin and Eosin; Scale bars represent $100 \mu$

Repeated oral administration of CELE daily for $90 \mathrm{~d}$ in this study showed certain abnormalities in the mice. The significant reduction in weight gain observed in the mice treated with $1000 \mathrm{mg} / \mathrm{kg}$ CELE daily for $90 \mathrm{~d}$, could suggest that the extract affected the mice's feed intake ${ }^{[10,36]}$ or has resulted in the reduction in the deposition of fats ${ }^{[37,38]}$. Decreased body weight gain in animals has been associated with toxicity following exposure to potential toxic chemical or substances ${ }^{[39,40]}$. These findings are in agreement with the report of
Chavalittumrong et al. ${ }^{[41]}$, where a significant decrease in body weight of male rats treated with $1000 \mathrm{mg} / \mathrm{kg}$ of $C$. nutans ethanolic extract daily for $90 \mathrm{~d}$ compared to the control group was observed. Similarly, Aliyu et al. ${ }^{[10]}$ reported a significant decreased in the body weight gain of mice administered with repeated doses of C. nutans daily for $28 \mathrm{~d}$ at 500 and $1000 \mathrm{mg} / \mathrm{kg}$ doses ${ }^{[10]}$. However, the result is contrary to the report of Zakaria et al..$^{[15]}$, who reported that repeated oral administration of methanolic extract of $C$. nutans daily for $28 \mathrm{~d}$ did not affect the body weight of the mice even 
at the highest dose of 2500. This perhaps may be due to shorter duration of exposure ${ }^{[39,40]}$ compared to the present study.

Previous study from our group by Aliyu et al. ${ }^{[10]}$ has shown that oral administration of high dose of CELE at $2000 \mathrm{mg} / \mathrm{kg}$ once and repeated oral administration of lower doses of the extract at $125 \mathrm{mg} / \mathrm{kg}, 250 \mathrm{mg} / \mathrm{kg}, 500$ $\mathrm{mg} / \mathrm{kg}$ and $1000 \mathrm{mg} / \mathrm{kg}$ daily for $28 \mathrm{~d}$ did not affect the haematological parameters of ICR mice ${ }^{[10]}$. However, administration of the extract for longer duration of $90 \mathrm{~d}$ in the current study resulted in abnormal haematological values. The significant increase in total White Blood Cells (WBCs) and differential counts, particularly the neutrophilia and monocytosis observed in the mice administered $1000 \mathrm{mg} / \mathrm{kg}$ CELE daily for $90 \mathrm{~d}$, indicates some ongoing inflammatory condition ${ }^{[42]}$ in the mice, perhaps due to some adverse effects of the extracts on some vital organs. The neutrophilia and increased lymphocytes and eosinophils counts observed in this study were contrary to the earlier reports by Sajjaratul et al. ${ }^{[5]}$, Zakaria et al..$^{[15]}$ and P'ng et al. ${ }^{[16]}$, who found that repeated administration of $C$. nutans extracts did not affect the haematological parameters of both rats and mice. The differences could be due to the shorter duration of administration ${ }^{[15,16]}$, different experimental animals ${ }^{[5,16]}$ and/or different extraction solvents used $^{[9,43-45]}$.

The results of plasma biochemical parameters showed that daily oral administration of CELE for $90 \mathrm{~d}$ at 500 and $1000 \mathrm{mg} / \mathrm{kg}$ doses has effect on some plasma biochemical parameters. The significant increase in urea observed at $1000 \mathrm{mg} / \mathrm{kg}$ dose and increase in creatinine level seen at 125, 250, 500 and $1000 \mathrm{mg} / \mathrm{kg}$ for $90 \mathrm{~d}$ in this study, suggested that the extract especially at higher doses of 500 and $1000 \mathrm{mg} / \mathrm{kg}$ may possess some adverse effects on the kidneys of the ICR mice ${ }^{[46-48]}$. This is because creatinine, which is the product of creatine metabolism, is solely excreted by the kidneys, hence any injury to the kidneys may result in hypercreatinaemia and therefore creatinine is considered as an important marker of renal injury ${ }^{[49]}$. These findings were similar to the report of Zakaria et al. ${ }^{[15]}$ and Aliyu et al. ${ }^{[10]}$, where there was significant increase in the level of creatinine in both male and female mice treated with both 500 and $1000 \mathrm{mg} / \mathrm{kg} \mathrm{C}$. nutans repeatedly for $28 \mathrm{~d}$. However, Chavalittumrong et $a .^{[41]}$ reported a significant decrease in the creatinine levels in the male rats treated with $1000 \mathrm{mg} / \mathrm{kg} \mathrm{C}$. nutans ethanolic extract daily for $90 \mathrm{~d}$ compared to the control. The notable elevation in the levels of ALT, AST and CK in the group treated with 500 and $1000 \mathrm{mg} / \mathrm{kg}$ CELE daily for $90 \mathrm{~d}$, could suggest that the extract at these high doses might have affected the normal function of liver and/or muscles in the treated mice ${ }^{[47,50,51]}$. This was further confirmed by the results of the histopathological evaluation of liver in this study. Increased serum activities of AST and CK, with a corresponding increase in Lactate Dehydrogenase (LDH) activity are associated with muscle injury, increased muscle activity or myocardial infarction $^{[52]}$. However, the significant elevation in the levels of AST in this study may be associated with the release of the enzymes from other organs of the body, including skeletal muscles, kidneys, erythrocytes, lungs, pancreas, brain, lungs and heart ${ }^{[21,50]}$.

The histopathological evaluation of liver and kidney of the experimental mice in this study, revealed that daily oral administration of CELE for $90 \mathrm{~d}$ at $1000 \mathrm{mg} / \mathrm{kg}$ dose resulted in various hepatic and renal lesions. The significant hepatic degeneration and necrosis observed histopathologically in the group of mice administered with daily oral doses of CELE at $1000 \mathrm{mg} / \mathrm{kg}$ for $90 \mathrm{~d}$ were suggestive of toxic or adverse effects ${ }^{[5,53,54]}$ of the extract on the animals, as earlier observed in the results of plasma biochemical parameters for hepatic injury markers (ALT and AST). Similarly, the renal tubular degeneration and necrosis observed in this study further justified the elevation of AST level, which also corroborate the increase in the plasma creatinine levels. These also provide more indication that administration of the extract at $1000 \mathrm{mg} / \mathrm{kg}$ is not safe ${ }^{[3,54]}$ in the treated mice. Severe hepatic damage has been reported to be associated with oxidative stress and depletion of Adenosine triphosphate (ATP) leading to necrosis of hepatocytes ${ }^{[55,56]}$. Nevertheless, the significant increase in the kidney injury marker observed in the groups treated with 125 and $250 \mathrm{mg} / \mathrm{kg}$ of the extract did not tally with the histological findings. This may suggest that the increased plasma concentration of urea and creatinine at these lower concentrations of the extract could be due to pre or post renal azotaemia resulting from either muscle injury, increased protein catabolism or blockage in the lower urinary tract ${ }^{[47,57]}$.

The interstitial oedema observed in this study could suggest further that the extract might have induced renal injury in the treated mice and also indicated by the hypoalbuminaemia observed in the CELE treated groups of mice ${ }^{[58]}$, which might have resulted from Protein Losing Nephropathy (PLN). Decreased ALB levels in the treated mice could affect the effective colloid osmotic pressure gradient negatively, thereby 
causing excess filtration of fluid from the intravascular to interstitial spaces ${ }^{[59,60]}$ portrayed by oedema of the renal interstitium (interstitial oedema) in the treated mice. Alternatively, the decreased level of ALB observed in the treated mice, could be due to decrease feed intake $\mathrm{e}^{[37,38]}$ and/or liver disease ${ }^{[47,50,51]}$, as depicted by the decreased body weight gains of the mice and the significant alterations in the liver injury markers (ALT and AST). Renal interstitial oedema may also be as a result of renal inflammation ${ }^{[61]}$, as indicated by the significant neutrophilia, monocytosis and cellular infiltrations in the group of mice treated with 500 and $1000 \mathrm{mg} / \mathrm{kg}$ of the extract. Tanaka and Nangaku ${ }^{[61]}$ reported that tubular interstitial nephritis is characterized histologically by inflammatory changes including interstitial oedema, leukocyte infiltration, accumulation of extracellular matrix proteins, tubular dilation and renal atrophy in the tubulointerstitial compartment. The inflammation observed in this study, might have caused increase vascular permeability leading to escape of fluid into the renal interstitium ${ }^{[59]}$. Similarly, the ongoing inflammatory process might have triggered the release of inflammatory mediators causing vasodilation and inducing leukocytes infiltration ${ }^{[59]}$.

It is concluded from this study that, repeated oral doses of CELE for $90 \mathrm{~d}$ induced significant hepatic and renal degeneration and necrosis at $1000 \mathrm{mg} / \mathrm{kg}$ in female ICR mice. Hence, the plant extract at this dose may be considered unsafe for medicinal purposes and/or food supplementation.

\section{Funding:}

This work was supported by IPS Research Grant (IPS/2018/9594600) Universiti Putra Malaysia and PhD scholarship was provided by Tertiary Education Trust Fund (TETFUND) Nigeria (Ref: TETFUND/ES/ AST\&D/UDU/SOKOTO/VOL.1/05/25/2016).

\section{Acknowledgements:}

The authors appreciate the contributions of the Malaysian Agricultural Research Development Institute (MARDI), the staff of the Haematology and Clinical Biochemistry and Histopathology Laboratories, Faculty of Veterinary Medicine (Pn Darulmuqaamah Masud, Pn Noorain Azman, En Abdullah Misron, En Arman Addelan, Pn Jamila Jahari, Pn Latifah Mohd Hanan Cik Zainatuaishah Abdul Manap), Universiti Putra Malaysia (UPM) for providing technical support in carrying out this research.

\section{Conflict of interests:}

The authors declared no conflict of interest.

\section{REFERENCES}

1. Meyer JY, Lavergne C. Beautés fatales: Acanthaceae species as invasive alien plants on tropical Indo-Pacific Islands. Divers Distrib 2004;10(5-6):333-47.

2. Kunsorn P, Ruangrungsi N, Lipipun V, Khanboon A, Rungsihirunrat $\mathrm{K}$. The identities and anti-herpes simplex virus activity of Clinacanthus nutans and Clinacanthus siamensis. Asian Pac J Trop Biomed 2013;3(4):284-90.

3. Yahaya R, Dash GK, Abdullah MS, Mathews A. Clinacanthus nutans (Burm. F.) Lindau: An useful medicinal plant of southeast Asia. Int J Pharmacogn Phytochem Res 2015;7(6):124450 .

4. Alam A, Ferdosh S, Ghafoor K, Hakim A, Juraimi AS, Khatib $\mathrm{A}$, et al. Clinacanthus nutans: A review of the medicinal uses, pharmacology and phytochemistry. Asian Pac J Trop Biomed 2016;9(4):402-9.

5. Asyura SN, Hamzah H, Shaari RM, Sithambaram S, Mustapha NM. Blood profiles and histopathological changes of liver and kidney tissues from male Sprague Dawley rats treated with ethanol extracts of Clinacanthus nutans leaf. J Clin Toxicol 2016;6(329):1-10.

6. Zhang Y, Jiao J, Liu C, Wu X, Zhang Y. Isolation and purification of four flavone C-glycosides from antioxidant of bamboo leaves by macroporous resin column chromatography and preparative high-performance liquid chromatography. Food Chem 2008;107(3):1326-36.

7. Dampawan P, Huntrakul CH, Reutrakul V, Raston CL, White AH. Constituents of Clinacanthus nutans and the crystal structure of LUP-20 (29)-ene-3-one. J Sci Soc Thailand 1977;3(1):14-26.

8. Sakdarat S, Shuyprom A, Pientong C, Ekalaksananan T, Thongchai S. Bioactive constituents from the leaves of Clinacanthus nutans Lindau. Bioorg Med Chem 2009;17(5):1857-60.

9. Mustapa AN, Martin A, Mato RB, Cocero MJ. Extraction of phytocompounds from the medicinal plant Clinacanthus nutans Lindau by microwave-assisted extraction and supercritical carbon dioxide extraction. Ind Crops Prod 2015;74:83-94.

10. Aliyu A, Shaari MR, Ahmad Sayuti NS, Reduan MF, Sithambaram S, Noordin MM, et al. Subacute oral administration of Clinacanthus nutans ethanolic leaf extract induced liver and kidney toxicities in ICR mice. Molecules 2020;25(11):2631.

11. Tu SF, Liu RH, Cheng YB, Hsu YM, Du YC, El-Shazly M, et al. Chemical constituents and bioactivities of Clinacanthus nutans aerial parts. Molecules 2014;19(12):20382-90.

12. Huang D, Guo W, Gao J, Chen J, Olatunji JO. Clinacanthus nutans (Burm. f.) Lindau ethanol extract inhibits hepatoma in mice through upregulation of the immune response. Molecules 2015;20(9):17405-28.

13. Chelyn JL, Omar MH, Mohd Yousof NS, Ranggasamy R, Wasiman MI, Ismail Z. Analysis of flavone C-glycosides in the leaves of Clinacanthus nutans (Burm. f.) Lindau by HPTLC and HPLC-UV/DAD. Sci World J 2014;2014.

14. Khoo LW, Foong Kow AS, Maulidiani M, Lee MT, Tan CP, Shaari K, et al. Hematological, biochemical, histopathological and 1H-NMR metabolomics application in acute toxicity evaluation of Clinacanthus nutans water leaf extract. Molecules 2018;23(9):2172. 
15. Zakaria ZA, Rahim MH, Mohtarrudin N, Kadir AA, Cheema MS, Ahmad Z, et al. Acute and sub-chronic oral toxicity studies of methanol extract of Clinacanthus nutans in mice. Afr J Tradit Complement Altern Med 2016;13(2):210-22.

16. P'ng XW, Akowuah GA, Chin JH. Evaluation of the sub-acute oral toxic effect of methanol extract of Clinacanthus nutans leaves in rats. J Acute Dis 2013;2(1):29-32.

17. P'ng XW, Akowuah GA, Chin JH. Acute oral toxicity study of Clinacanthus nutans in mice. Int J Pharm Sci Res 2012;3(11):4202.

18. Mahdi H, Yousif E, Khan N, Mahmud R, Murugaiyah V, Asmawi M. Optimizing extraction conditions of Moringa oleifera LAM leaf for percent yield, total phenolics content, total flavonoids content and total radical scavenging activity. Int J Adv Res 2016;4:682-95.

19. Aliyu A, Alkali BR, Yahaya MS, Garba A, Adeleye SA, Gashua $\mathrm{MM}$, et al. Phytochemical analysis and antibacterial activity of Khaya senegalensis bark extracts on Bacillus subtilis, Escherichia coli and Proteus mirabilis. Int J Phytomedicine 2016;8:333-6.

20. Othman A, Ismail A, Ghani NA, Adenan I. Antioxidant capacity and phenolic content of cocoa beans. Food Chem 2007;100(4):1523-30.

21. Reduan FH, Shaari RM, Sayuti NS, Mustapha NM, Abu Bakar MZ, Sithambaram S, et al. Acute and subacute dermal toxicity of ethanolic extract of Melastoma malabathricum leaves in Sprague-Dawley rats. Toxicol Res 2020;36(3):203-10.

22. Nurul SA, Hazilawati H, Mohd RS, Mohd FH, Noordin MM, Norhaizan ME. Subacute oral toxicity assesment of ethanol extract of Mariposa christia vespertilionis leaves in male Sprague Dawley rats. Toxicol Res 2018;34(2):85-95.

23. Serfilippi LM, Stackhouse Pallman DR, Russell B, Spainhour CB. Serum clinical chemistry and hematology reference values in outbred stocks of Albino mice from three commonly used vendors and two inbred strains of Albino mice. J Am Assoc Lab Anim Sci 2003;42(3):46-52.

24. Aliyu A, Shaari MR, Ahmad Sayuti NS, Reduan MF, Sithambaram S, Noordin MM, et al. N-Ethyl-n-Nitrosourea induced leukaemia in a mouse model through upregulation of vascular endothelial growth factor and evading apoptosis. Cancers 2020;12(3):678.

25. Wiedmeyer CE, Ruben D, Franklin C. Complete blood count, clinical chemistry, and serology profile by using a single tube of whole blood from mice. J Am Assoc Lab Anim Sci 2007;46(2):59-64.

26. Awodele O, Oreagba IA, Odoma S, da Silva JA, Osunkalu VO. Toxicological evaluation of the aqueous leaf extract of Moringa oleifera Lam. (Moringaceae). J Ethnopharmacol 2012;139(2):330-6.

27. Kasolo JN, Bimenya GS, Ojok L, Ogwal-Okeng JW. Subacute toxicity evaluation of Moringa oleifera leaves aqueous and ethanol extracts in Swiss Albino rats. Int J Med Plant Res 2012;1(6):75-81.

28. Aliyu A, Natala AJ, Adamu S, Igbokwe IO, Esievo KA, Useh NM. A comparative study on the haematology, biochemical alterations in serum composition and pathologic changes in the kidneys of cachectic and non-cachectic cattle in Zaria, Nigeria. Int J Biochem Res Rev 2017;19:1-11.

29. Kodentsova VM, Vrzhesinskaya OA, Beketova NA, Soto SK, Karagodina ZV, Sharanova NE, et al. Biochemistry of blood plasma and some parameters of antioxidant status in rats with polyhypovitaminosis of varying severity. Bull Exp Biol Med 2013;154(4):445-8.
30. Fernandes DP, Pimentel MM, Santos FA, Praxedes EA, Brito PD, Lima MA, et al. Hematological and biochemical profile of BALB/c nude and C57BL/6 SCID female mice after ovarian xenograft. An Acad Bras Cienc 2018;90:3941-8.

31. Al-Shabanah OA, El-Hadiyah TM, Al-Majed AA. Effect of prolonged vigabatrin treatment on hematological and biochemical parameters in plasma, liver and kidney of Swiss albino mice. Sci Pharm 2002;70(2):135-45.

32. Keppler A, Gretz N, Schmidt R, Kloetzer HM, Gröne HJ, Lelongt $\mathrm{B}$, et al. Plasma creatinine determination in mice and rats: an enzymatic method compares favorably with a high-performance liquid chromatography assay. Kidney Int 2007;71(1):74-8.

33. Barle EL, Looser R, Černe M, Bechter R. The value of acute toxicity testing of pharmaceuticals for estimation of human response. Regul Toxicol Pharmacol 2012;62(3):412-8.

34. Mohd FH, Mohd RS, Sayuti NS, Aliyu A, Md NM, Bakar ZA, et al. Evaluation of dermal toxicity study of ethanolic extract of Morinda citrifolia fruit in Spraque Dawley rats. Thai J Vet Med 2021;51(1):101-9.

35. Timbrell JA. Principles of biochemical toxicology. $4^{\text {th }}$ ed. New York: CRC Press; 2008.

36. Ogbonnia SO, Mbaka GO, Anyika EN, Osegbo OM, Igbokwe NH. Evaluation of acute toxicity in mice and subchronic toxicity of hydroethanolic extract of Chromolaena odorata (L.) King and Robinson (Fam. Asteraceae) in rats. Am J Agric Biol Sci 2010;1(5):859-65.

37. Priestman DA, Van Der Spoel AC, Butters TD, Dwek RA, Platt FM. N-butyldeoxynojirimycin causes weight loss as a result of appetite suppression in lean and obese mice. Diabetes Obes Metab 2008;10(2):159-66.

38. Harizal SN, Mansor SM, Hasnan J, Tharakan JK, Abdullah J. Acute toxicity study of the standardized methanolic extract of Mitragyna speciosa Korth in rodent. J Ethnopharmacol 2010;131(2):404-9.

39. Rajeh MA, Kwan YP, Zakaria Z, Latha LY, Jothy SL, Sasidharan S. Acute toxicity impacts of Euphorbia hirta L extract on behavior, organs body weight index and histopathology of organs of the mice and Artemia salina. Pharmacognosy Res 2012;4(3): 170 .

40. Teo S, Stirling D, Thomas S, Hoberman A, Kiorpes A, Khetani V. A 90 d oral gavage toxicity study of d-methylphenidate and d, 1-methylphenidate in Sprague-Dawley rats. Toxicology 2002;179(3):183-96.

41. Chavalittumrong P, Attawish A, Rugsamon P, Chuntapet P. Toxicological study of Clinacanthus nutans (Burm. f.) Lindau. Warasan Krom Witthayasat Kan Phaet 1995;37(4):323-38.

42. Saganuwan SA, Aondoaver AD, Roman IT. Reassessment of acute and chronic toxicity effects of aqueous leaf extract of Morinda lucida in Rattus norvegicus. J Hematol Res 2014;1(1):36-46.

43. Tan MC, Tan CP, Ho CW. Effects of extraction solvent system, time and temperature on total phenolic content of henna (Lawsonia inermis) stems. Int Food Res J 2013;20(6):3117-23.

44. Senguttuvan J, Paulsamy S, Karthika K. Phytochemical analysis and evaluation of leaf and root parts of the medicinal herb, Hypochaeris radicata $\mathrm{L}$. for in vitro antioxidant activities. Asian Pac J Trop Biomed 2014;4:S359-67.

45. Mahdi H, Yousif E, Khan N, Mahmud R, Murugaiyah V, Asmawi M. Optimizing extraction conditions of Moringa oleifera LAM leaf for percent yield, total phenolics content, total flavonoids content and total radical scavenging activity. Int J Adv Res 2016;4:682-95. 
46. Gad MM, Mohammad YS, Mohammad TG. Acute and repeated-doses ( $28 \mathrm{~d}$ ) toxicity of Thymol formulation in male Albino rats. Aust J Basic Appl Sci 2013;7(10):594-601.

47. Bush BM. Interpretation of laboratory results for small animal clinicians. Blackwell Scientific Publications Ltd; 1991.

48. Evans G. Animal clinical chemistry. $2^{\text {nd }}$ ed. A practical handbook for toxicologists and biomedical researchers. CRC Press; 2009.

49. Braun JP, Lefebvre HP. Kidney function and damage. In: Clinical biochemistry of domestic animals. Elsevier; 2008. p. 485-528.

50. Tennant BC, Center SA. Hepatic Function. In: Clinical biochemistry of domestic animals. Elsevier; 2008. p. 379-412.

51. Rhiouani H, El-Hilaly J, Israili ZH, Lyoussi B. Acute and subchronic toxicity of an aqueous extract of the leaves of Herniaria glabra in rodents. J Ethnopharmacol 2008;118(3):378-86.

52. Schwane JA, Johnson SR, Vandenakker CB, Armstrong RB. Delayed-onset muscular soreness and plasma CPK and LDH activities after downhill running. Med Sci Sports Exerc 1983;15(1):51-6.

53. Kiss N, Hamar P. Histopathological evaluation of contrastinduced acute kidney injury rodent models. Biomed Res Int 2016;2016.

54. Itagaki SI, Nishida E, Lee MJ, Doi K. Histopathology of subacute renal lesions in mice induced by streptozotocin. Exp Toxicol Pathol 1995;47(6):485-91.

55. Bantel H. Mechanisms of cell death in acute liver failure. Front Physiol 2012;3:79.

56. Hinson JA, Roberts DW, James LP. Mechanisms of acetaminophen-induced liver necrosis. In: Handbook of experimental pharmacology. 2010. p. 369-405.

57. Kreutzer KV, Turk JR, Casteel SW. Clinical biochemistry in toxicology. In: Clinical biochemistry of domestic animals. Elsevier; 2008. p. 821-37.

58. Aliyu A, Shaari MR, Sayuti NSA, Reduan MFH, Sithambaram S, Noordin MM, et al. Moringa oleifera hydroethanolic leaf extract induced acute and sub-acute hepato-nephrotoxicity in Female ICR-Mice. Sci Prog; 2021.

59. Scallan J, Huxley VH, Korthuis RJ. Capillary fluid exchange: Regulation, functions, and pathology. In: Colloquium lectures on integrated systems physiology: From molecules to function. Morgan \& Claypool Publishers 2010;2(1):1-94.

60. Siddall EC, Radhakrishnan J. The pathophysiology of edema formation in the nephrotic syndrome. Kidney Int 2012;82(6):635-42.

61. Tanaka T, Nangaku M. Pathogenesis of tubular interstitial nephritis. In: Experimental models for renal diseases. Basel: Karger Publishers; 2011. p. 297-310. 